\title{
Paramyotonia Congenita
}

National Cancer Institute

\section{Source}

National Cancer Institute. Paramyotonia Congenita. NCI Thesaurus. Code C122790.

An autosomal dominant inherited non-dystrophic myotonia caused by mutations of the SCN4A gene, resulting in sodium muscle channelopathy. It is characterized by muscle stiffness, which is increased by exposure to cold or activity, and usually eases when the patient warms up through physical activity. 